\title{
Utility of Microwave and Optical Remote Sensing in Oil Spill Detection in the Mangrove Region of Nigeria
}

\author{
Toju Francis Balogun \\ Department Geography and Regional Planning, University of Benin, Benin City, Nigeria \\ Email: tobalogun@yahoo.com
}

Received 20 February 2015; accepted 16 March 2015; published 23 March 2015

Copyright (C) 2015 by author and Scientific Research Publishing Inc.

This work is licensed under the Creative Commons Attribution International License (CC BY). http://creativecommons.org/licenses/by/4.0/

(c) (i) Open Access

\begin{abstract}
The mangrove interfaces between land and sea and provides appropriate ecosystem and habitat and breeding ground for fishes and sea animals. However, it is also a fragile ecosystem which is exposed to environmental degradation due to oil exploration activities. Concern for mangrove environment demands that mapping of the mangrove environment should be carried out so as to know its current status. Conventional method is inadequate to achieve this due to the difficult terrain of the region. This research aims at detecting and mapping the presence of oil spill on water and land in the mangroves using microwave and optical remote sensing. The result proves that optical remote sensing has the potentials for detecting oil spill on the waterway. It also has the capability to detect oil spill on ground using the effects of oil on vegetation as proxy. The study is concluded by recommending further research work on radar as it could not discriminate between the backscatter of oil on land and that of soil with high water content.
\end{abstract}

\section{Keywords}

Mangrove, Fragile Ecosystem, Environmental Degradation, Oil Spill, Monitoring

\section{Introduction}

The mangrove plants in the Niger Delta cover approximately $6000 \mathrm{~km}^{2}$ between the fresh water zone and the belt of beach-ridges, which form the seaward boundary [1] [2]. The mangrove in Nigeria is the third largest in the world and the largest in Africa [1]. It is an ecosystem that is rich in biodiversity. The creeks and the mangroves of the Niger Delta belong to a fragile ecosystem and are exposed to the possibility of oil spill due to oil exploration either through accident or sabotage which usually results into environmental degradation. Detection, 
mapping and monitoring are problematic because of various factors such as canopy cover which prevents the ground from being "seen" and the problem of cloud cover which reduces the available window for optical image acquisition. The inaccessible nature of the ecosystem and the insecurity preclude detailed fieldwork demand alternative option of providing necessary and urgent information for the remediation group in case of oil spill in the creeks.

Although there are several studies on oil spill detection and mapping in the marine environment using remote sensing [3]-[6], there is a dearth of information to better understand the contribution of remote sensing to oil spill detection and mapping in the mangroves and creeks. Therefore, the primary aim of this study is to utilize microwave and optical remote sensing datasets to determine their usefulness in detecting and mapping oil spill in Awoba and Krakrama axis of the Niger Delta.

\section{Study Area}

Awoba and Krakrama axis is located in southwest of Port Harcourt. It lies within $6^{\circ} 45^{\prime} 00^{\prime \prime} \mathrm{E} ; 4^{\circ} 30^{\prime} 0^{\prime \prime} \mathrm{N}$ and $6^{\circ} 53^{\prime} 0 " \mathrm{E} ; 4^{\circ} 35^{\prime} 0 " \mathrm{~N}$ coordinates. Awoba and Krakrama axis is a major settlement in Degema Local Government Area in Rivers State of Nigeria. The Local government is located within the mangrove forest (See Figure 1: the study area map). A major and prominent attraction in the study area is the Nembe Creek Trunkline (NCTL) pipeline which has been vandalized several times by the oil bunkerers and reported in the national news.

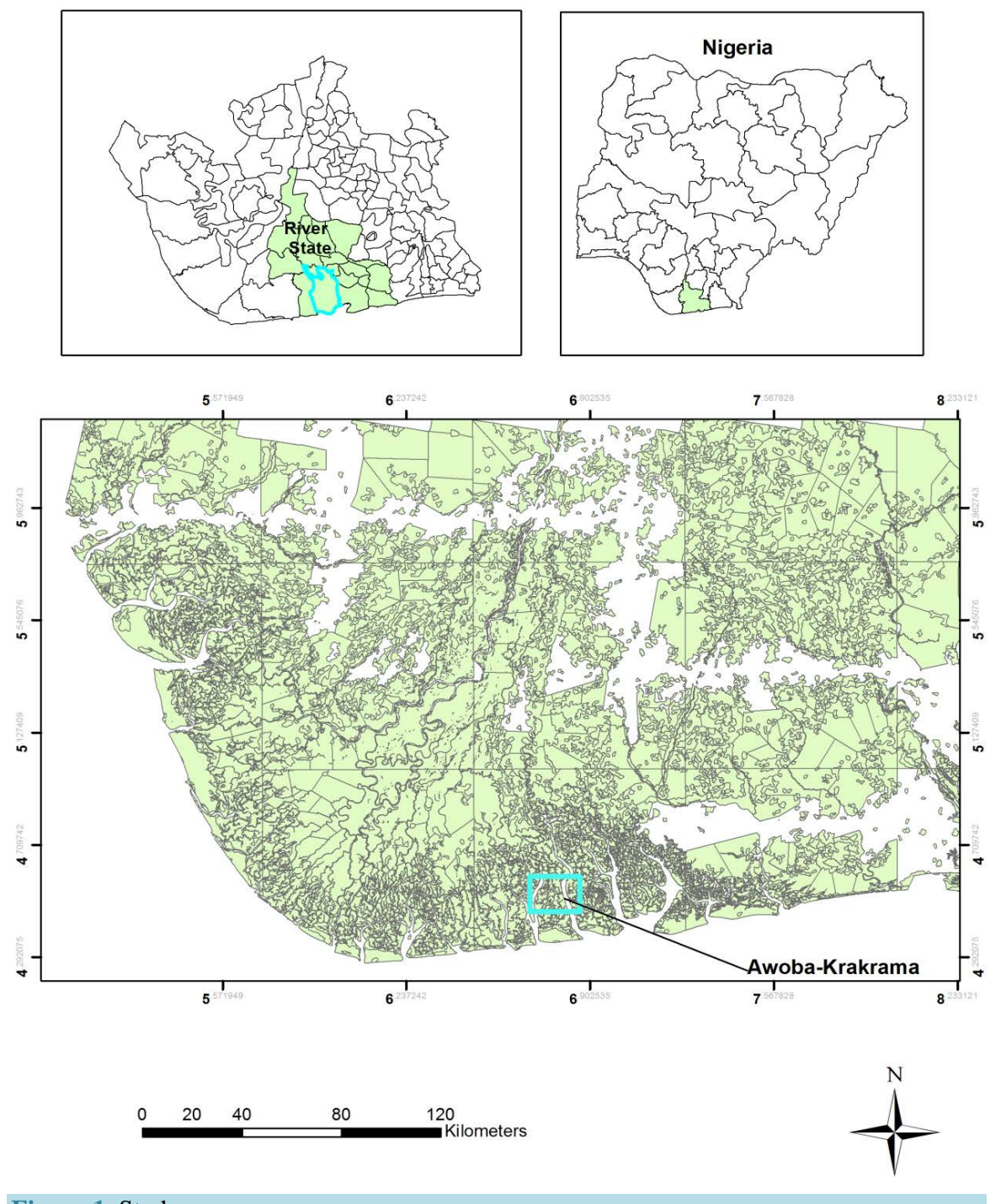

Figure 1. Study area. 


\section{Materials and Methods}

This study utilized Worldview-2, a high resolution optical image acquired $9^{\text {th }}$ January 2013 and Synthetic Aperture Radar (SAR), a microwave image acquired on $22^{\text {nd }}$ December 2012. Datasets were geometrically corrected, rectified to the true ground positions and projected to the Transverse Mercator Nigeria Mid-Belt (WGS-1984) and referenced to the Minna Datum. Digital image processing was carried out with Erdas Imagine 2010 software. Proxy that could be used to determine the presence/impact of oil spill in the image was used. Direct method based on texture and spectral signature was also utilized.

False color composite was created to aid image interpretation and processing as it gave a better visual impression of the reality on the ground than displaying one band at a time. This results in an image with realistic colors though the colors in the image are not the same as in reality. A false-color image sacrifices natural color rendition (in contrast to a true-color image) in order to ease the detection of features that are not readily discernible otherwise, for example the use of near infrared for the detection of vegetation in satellite images. This false color composite scheme allows vegetation to be detected readily in the image. In this type of false color composite images, vegetation appears in different shades of red depending on the types and conditions of the vegetation, since it has a high reflectance in the NIR band. Clear water appears dark-bluish (higher green band reflectance), while turbid water appears cyan (higher red reflectance due to sediments) compared to clear water. Bare soils, roads and buildings may appear in various shades of blue, yellow or grey, depending on their composition. This understanding was applied in the selection of training sites for the supervised classification. Training sites selected were used to generate statistics for signature analysis. The software was then used to classify the images using Maximum Likelihood Classification (MLC) Algorithm.

\section{Results and Discussion}

In the land cover classification of 2012 radar image mangrove vegetation covers $151 \mathrm{~km}^{2}$, swamps $60.4 \mathrm{~km}{ }^{2}$ and river $59.7 \mathrm{~km}^{2}$ (Figure 2). There are two additional classes which are absent in the SAR image but appear clearly in the optical image. These are stressed vegetation which covers about $37.6 \mathrm{~km}^{2}$ and oil on water covering $9.2 \mathrm{~km}^{2}$ (Figure 3). This proves that optical image is good in detecting and mapping oil on water as it appears as sheen on water. On the land, oil spill is detectable using the reflectance characteristic of the stress vegetation as proxy.

The study demonstrates that using optical remote sensing data is possible to assess the condition of the mangrove ecosystem as degradation of the mangrove forest is observable in the interpreted image. The degraded mangrove forest is close to NCTL pipeline which suffered illegal bunkering several times in 2012 and 2013 . It is also close to where illegal refineries are rampant. Thus it may be possible that spill from illegal refineries activities could have been responsible for the degraded mangrove forest. This is a major threat to mangrove forest.

The destruction of mangrove ecosystems can reduce production of coastal fisheries, because mangrove forests serve as breeding and nursery grounds for many commercial species of fish, crustaceans and mollusks [7] [8]. Mangrove ecosystems support aquatic food chains and form habitats for marine fauna, such as juvenile crabs, prawns, offshore fish, reef fish, and larvae [9]-[12]. In the Niger Delta, mangrove wood is a source of fuel, either as charcoal or firewood, and is a primary material for the construction of boats, houses, furniture, etc. According to [13] timber resources, especially the non-timber forest product (NTFRs) are critical sources of income for many rural household. In River State alone, the estimated value of NTFRs may exceed USD 100 million annually. The fragility of the ecosystem and its exposure to environmental degradation arising from oil exploration makes the monitoring and protection of mangroves an urgent priority.

\section{Conclusions}

The study demonstrates the potentials of remote sensing method in detecting and mapping oil spill in the mangrove. Study reveals that the mangrove is experiencing significant changes due to oil spillages arising from oil bunkering and illegal refinery. Oil spill has devastating effects on the environment. The result of this study is a pointer to what may be going on in other areas where crude oil theft is rampant. Mangrove mapping is an important technical task for managing natural resources as vegetation provides a base for all living beings and plays an essential role in affecting global climate change such as influencing terrestrial $\mathrm{Co}_{2}$ [14]. It is on this ground that this study suggests a regional survey of the mangrove in the Niger Delta using optical remote sensing 


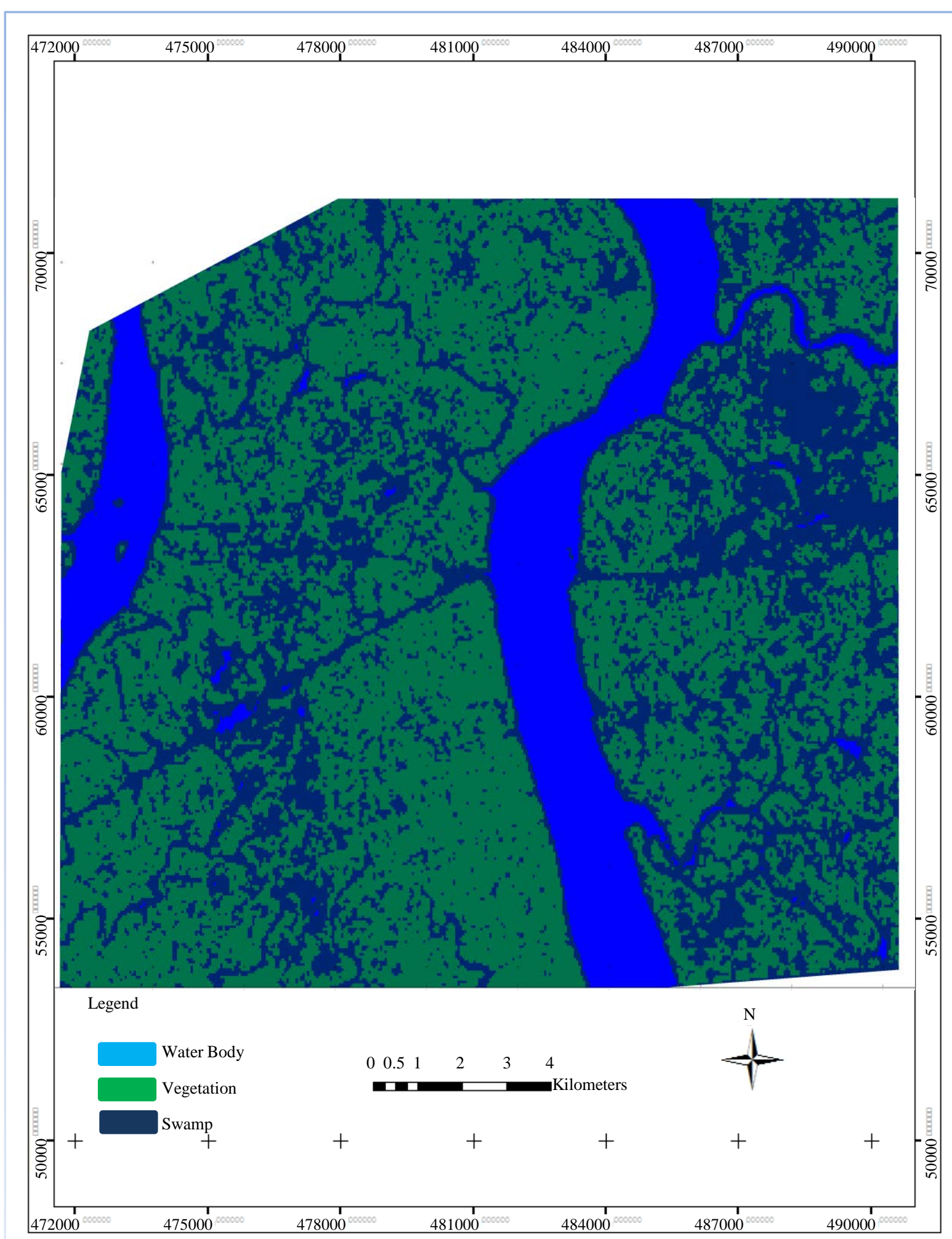

Figure 2. Land cover classification from Radar image of 2012.

method. Using worldview-2 image proves that higher resolution images are better for mangrove mapping; however, the cost of per square kilometre is also high. 


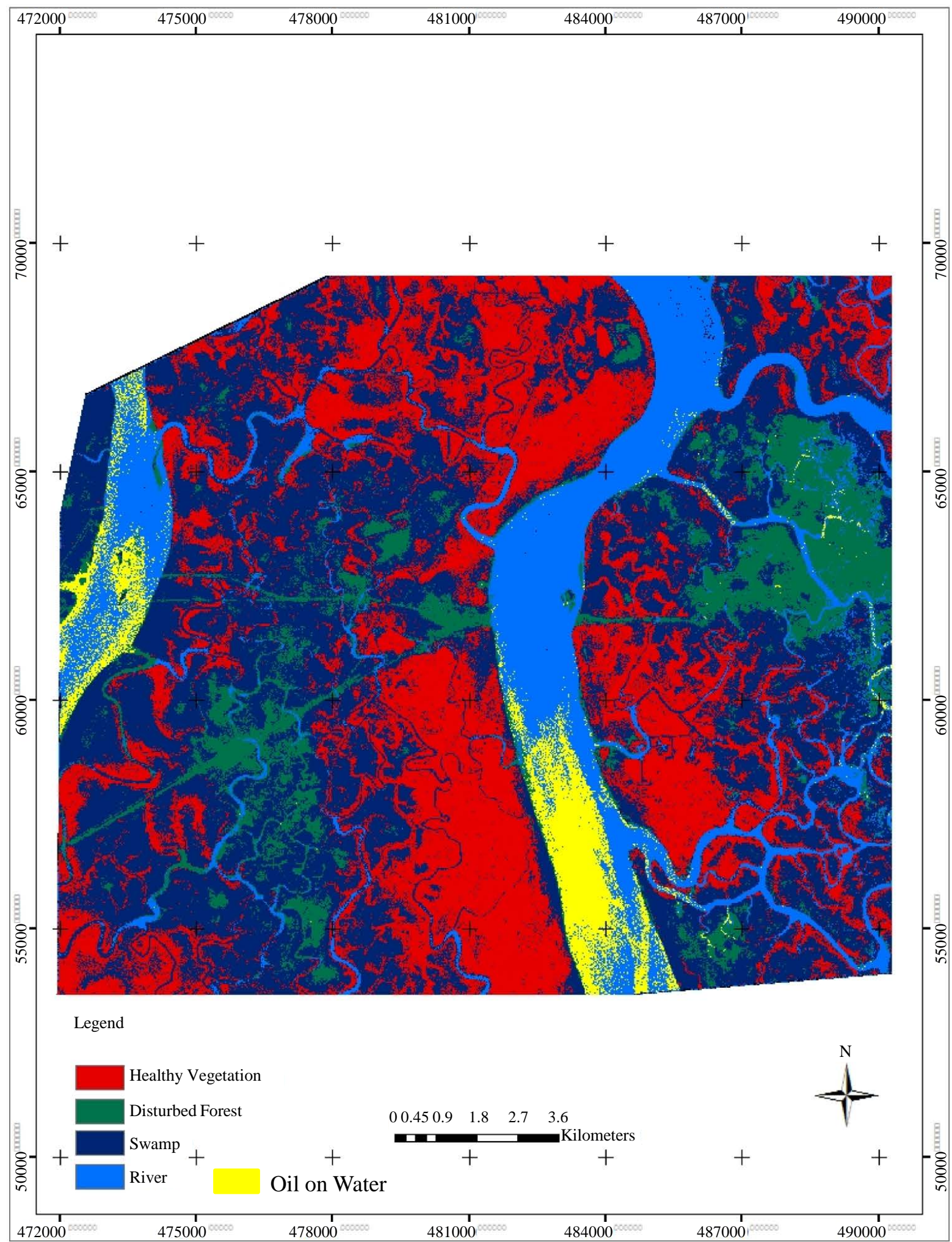

Figure 3. Land cover classification from 2013 Worldview-2.

More research work on the use of radar in monitoring oil on land is required due to its inability to discriminate between the backscatter of soil with high moisture content and that of oil on land. As observed in this study, 
optical remote sensing is good for oil spill detection and mapping but it has small imaging window due to cloud cover whereas radar can operate day and night and during cloud cover. Thus, a synergy of optical and microwave remote sensing would provide a powerful means of detecting and mapping of oil spill in the mangrove. To achieve this, more research work on the use of radar is therefore suggested. This study confirms [15] that the technology of remote sensing offers a practical and economical means to study mangrove especially over a large area. Remote sensing is cost saving and it also reduces the exposure to insecurity in the difficult terrain like Niger Delta.

\section{References}

[1] Moffac, D. and Linden, O. (1995) Perception and Reality: Assessing Priorities for sustainable Develoment in the Niger Delta. AMBIO: A Journal of Human Environment, 24, 527-538.

[2] Anderson, B. (1997) Reports on the Soils of the Niger Delta Special Area. Delta Development Board, Port Harcourt, $413 \mathrm{p}$.

[3] Jha, M.N., Levy, J. and Gao, Y. (2008) Advances in Remote Sensing for Oil Spill Disaster Management: State-of-theArt Sensors Technology for Oil Spill Surveillance. Sensors, 8, 236-255. http://dx.doi.org/10.3390/s8010236

[4] Brekke, C. and Solberg, A.H.S. (2005) Oil Spill Detection by Satellite Remote Sensing. Remote Sensing of Environment, 95, 1-13. http://dx.doi.org/10.1016/j.rse.2004.11.015

[5] Zhao, J., Temimi, M., Ghedira, M. and Hu, C. (2014) Exploring the Potential of Optical Remote Sensing for Oil Spill Detection In Shallow Coastal Waters-A Case Study in the Arabian Gulf. Optics Express, 22, 13755-13772.

[6] Ivanov, A. and Zatyagalova, V.V. (2008) A GIS Approach to Mapping Oil Spills in a Marine Environment. International Journal of Remote Sensing, 29, 6297-6313. http://dx.doi.org/10.1080/01431160802175587

[7] Boyd, C.E. and Tucker, C.S. (1998) Pond Aquaculture Water Quality Management. Springer Publishing, New York. http://dx.doi.org/10.1007/978-1-4615-5407-3

[8] Ramachandran, S., Sundaramoorty, S., Krishnamoorty, S., Devasenapaty, J. and Thanikachalam, M. (1998) Application of Remote Sensing and GIS to Coastal Wetland of Tamil Nadu. Current Science, 75, 236-239.

[9] Manson, F.J., Loneragan, N.R., Skilleter, G.A. and Phinn, S.R. (2005) An Evaluation of the Evidence for Linkages between Mangroves and Fisheries: A Synthesis of the Literature and Identification of Research Directions. In: Gibson, R.N., Atkinson, R.J.A. and Gordon, J.D.M., Eds., Oceanography and Marine Biology: An Annual Review, Volume 43, Taylor and Francis, London, 485-515.

[10] Mumby, P.J., Edwards, A.J., Arias-Gonzáles, E., Lindeman, K.C., Blackwell, P.G., Gall, A., Gorczynska, M.I., Harborne, A.R., Pescod, C.L., Renken, H., Wabnitz, C.C. and Llewellyn, G. (2004) Mangroves Enhance the Biomass of Coral Reef Fish Communities in the Caribbean. Nature, 427, 533-536. http://dx.doi.org/10.1038/nature02286

[11] Nagelkerken, I., Blaber, S.J.M., Bouillon, S., Green, P., Haywood, M., Kirton, L.G., Meynecke, J.-O., Pawlik, J., Penrose, H.M., Sasekumar, A. and Somerfield, P.J. (2008) The Habit Function of Mangroves for Terrestrial and Marine Fauna: A Review. Aquatic Botany, 89, 155-185. http://dx.doi.org/10.1016/j.aquabot.2007.12.007

[12] Naylor, R.L., Goldburg, R.J., Primavera, J.H., Kautsky, N., Beveridge, M.C.M., Clay, J., Folke, C., Lubchenco, J., Mooney, H. and Troell, M. (2000) Effect of Aquaculture on World Fish Supplies. Nature, 405, 1017-1024. http://dx.doi.org/10.1038/35016500

[13] Ruitenbeck, J.H. (1990) Economic Analysis of Tropical Forest Conservation Initiatives: Example from West Africa. World Wide Fund for Nature, Gland.

[14] Xiao, X.M., Zhang, Q.Y., Braswell, B., Urbanski, S., Boles, S., Wofsy, S., Moore III, B. and Ojima, D. (2004) Modeling Gross Primary Production of Temperate Deciduous Droadleaf Forest Using Satellite Images and Climate Data. Remote Sensing of Environment, 91, 256-270. http://dx.doi.org/10.1016/j.rse.2004.03.010

[15] Langley, S.K., Cheshire, H.M. and Humes, K.S. (2001) A Comparison of Single Date and Multitemporal Satellite Image Classifications in a Semi-Arid Grassland. Journal of Arid Environments, 49, 401-411.

http://dx.doi.org/10.1006/jare.2000.0771 